\title{
PENGARUH REKRUTMEN DAN PENEMPATAN PEGAWAI TERHADAP KINERJA PADA SATUAN KERJA DINAS BINA MARGA DAN TATA RUANG PROVINSI BANTEN
}

\author{
Tutik Siswanti dan Encop Sopiah
}

\begin{abstract}
ABSTRAK
Pegawai mempunyai peran yang utama dalam setiap kegiatan organisasi, karena pegawai menjadi perencana, pelaku, dan penentu terwujudnya tujuan sistem organisasi. Tujuan organisasi akan lebih mudah dicapai apabila pegawai ditempatkan pada posisi yang sesuai dengan kompetensi yang dimilikinya. Tetapi kompetensi dan kemampuan saja tidak cukup untuk meningkatkan kinerja pegawai, dibutuhkan juga ketepatan dalam menempatkan pegawai sesuai dengan kompetensi dan kemampuannya. Penelitian ini dilakukan pada obyek penelitian Dinas Bina Marga dan Tata Ruang Propinsi Banten, sedangkan jenis penelitiannya adalah eksplanatori dengan pendekatan kuantitatif. Variabel bebas yang digunakan dalam penelitian ini adalah rekruitmen pegawai (XI) dan penempatan pegawai (X2), sedangkan variabel terikatnya $(Y)$ adalah kinerja pegawai.

Populasi dalam penelitian ini adalah seluruh karyawan tetap Dinas Bina Marga dan Tata Ruang Propinsi Banten yang berjumlah 36 orang. Dikarenakan jumlah populasi kurang dari 100, maka seluruh populasi digunakan sebagai sampel, sehingga menggunakan sampel jenuh. Hasil analisis penelitian menunjukkan bahwa variabel rekruitmen pegawai(X1) mempunyai pengaruh negatif terhadap variable kinerja pegawai $(Y)$, dengan nilai -0,333, sedangkan variabel penempatan pegawai memiliki hubungan yang positif dan signifikan terhadap variabel kinerja dengan hasil sebesar 0,495.

Hasil Uji hipotesis parsial menunjukkan bahwa, secara individu rekruitmen tidak berpengaruh terhadap kinerja pegawai, sehingga $H_{0}$ diterima dan $H_{a}$ di tolak. Sedangkan penempatan pegawai berdasarkan hipotesisi memiliki pengaruh terhadap kinerja, sehingga $\mathrm{H}_{0}$ di tolak dan $\mathrm{H}_{a}$ diterima. Hasil uji hipotesis simultan menunjukan secara bersama-sama/serentak rekruitmen dan penempatan pegawai berpengaruh terhadap kinerja, sehingga $H_{0}$ di tolak dan $H_{a}$ diterima.

Hasil koefisien determinasi $R$ square dengan nilai 0,167, hal ini mengindikasikan bahwa varaiasi variabel terikat mampu dijelaskan oleh varaibel bebas sebesar 16,7\%.
\end{abstract}

Kata kunci: rekruitmen, penempatan pegawai, kesesuaian pengetahuan, kesesuaian kemampuan, kesesuaian keahlian, kinerja.

\section{PENDAHULUAN}

\subsection{Latar Belakang Masalah}

Dinas Bina Marga dan Tata Ruang Propinsi Banten merupakan instansi pemerintah yang memiliki tugas pokok dan fungsi dalam pengkoordinasian kebijakan pelayanan daerah di bidang perencanaan tata ruang, pengendalian pemanfaatan lahan, penatagunaan lahan serta penataan bangunan. Adapun tugas pokok tersebut antara lain penyusunan rencana strategis dinas berdasarkan rencana strategis pemerintah daerah, perumusan kebijakan teknis bidang bina marga dan bidang tata ruang sesuai rencana strategis dinas. Berkaitan dengan tugas dan fungsinya, maka Dinas Bina Marga dan Tata Ruang Propinsi Banten membutuhkan pegawai yang memiliki latar belakang pendidikan, ketrampilan, pengalaman serta kemampuan yang sesuai dengan bidang tersebut. Hal ini untuk menciptakan kualitas pekerjuaan yang baik serta kinerja yang maksimal. 
Kinerja pegawai dapat dicapai dengan maksimal, jika didukung dengan tingkat kemampuan pegawai, sedangkan tingkat kemampuan pegawai sangat erat kaitannya dengan komptensi yang dimilikinya. Kompetenasi pegawai tentu saja tergantung dari latar belakang pendidikan, sertifikasi atas kemampuan dan ketrampilan yang dimilikinya. Dengan kemampuan sesuai dengan bidangnya dan pelakukan pekerjaan yang sesuai, maka kinerja pegawai akan dapat tercapai dengan baik.

Dinas Bina Marga dan Tata Ruang Propinsi Banten tentu juga mengharapkan kinerja pegawai pada intsansi tersebut dapat tercapai secara maksimal, sehingga dapat memberikan kualitas pelayanan kepada masyarakat lebih baik. Namun demikian dalam kenyataannya kinerja pegawai masih belum sesuai dengan yang diharapkan. Oleh karena itu penelitian ini akan mengukur beberapa faktor yang mempengaruhi kinerja pegawai pada lingkungan Dinas Bina Marga dan Tata Ruang di Propinsi Banten.

\subsection{Batasan Masalah}

Kinerja karyawan merupakan faktor yang sangat penting dalam menentukan keberhasilan perusahaan/organisasi. Mengingat faktor-faktor yang mempengaruhi kinerja pegawai sangat komplek dan beragam, maka dalam penelitian ini agar fokus pada pembahasan perlu ada pembatasan masalah. Pembatasan masalah dalam penelitian ini terkait dengan pengaruh rekrutmen dan penempatan pegawai terhadap kinerja pada Satuan Kerja Dinas Bina Marga Dan Tata Ruang Provinsi Banten. Parameter yang digunakan untuk mengukur rekrutmen meliputi ; kebutuhan pegawai baik secara kuantitatif maupun kualitatif, proses seleksi dan proses penyaringan calon pegawai pada Satuan Kerja Dinas Bina Marga Dan Tata Ruang Provinsi Banten. Sedangkan parameter untuk mengukur penempatan pegawai adalah kualifikasi kebutuhan pegawai, latar belakang pendidikan, kemampuan, keahlian, dan pengalaman. Kinerja karyawan sendiri diukur dengan parameter ketepatan waktu, kerjasama, tanggungjawab dan pencapaian target.

\subsection{Rumusan Masalah}

Beradasarkan latar belakang dan identifikasi masalah, maka perumusan masalah dalam penelitian ini adalah sebagai berikut :

a. Bagaimana pengaruh Rekrutmen terhadap Kinerja pada Satuan Kerja Dinas Bina Marga Dan Tata Ruang Provinsi Banten ?

b. Bagaimana pengaruh Penempatan Pegawai terhadap Kinerja pada Satuan Kerja Dinas Bina Marga Dan Tata Ruang Provinsi Banten?

c. Bagaimana pengaruh Rekrutmen dan Penempatan Pegawai terhadap Kinerja pada Satuan Kerja Dinas Bina Marga Dan Tata Ruang Provinsi Banten? 


\subsection{Tujuan Penelitian}

Tujuan dari penelitian ini adalah untuk mengetahui :

a. Pengaruh Rekrutmen secara parsial terhadap Kinerja pada Satuan Kerja Dinas Bina Marga Dan Tata Ruang Provinsi Banten.

b. Pengaruh Penempatan Pegawai secara parsial terhadap Kinerja pada Satuan Kerja Dinas Bina Marga Dan Tata Ruang Provinsi Banten

c. Pengaruh Rekrutmen dan Penempatan Pegawai secara simultan terhadap Kinerja pada Satuan Kerja Dinas Bina Marga Dan Tata Ruang Provinsi Banten.

\section{TINJAUAN PUSTAKA}

\subsection{Manajemen Sumber Daya Manusia (MSDM)}

Menurut Marwansyah (2010), manajemen sumber daya manusia dapat diartikan sebagai pendayagunaan sumber daya manusia di dalam organisasi, yg dilakukan melalui fungsi-fungsi perencanaan sumber daya manusia, rekrutmen dan seleksi, pengembangan sumber daya manusia, perencanaan dan pengembangan karir, pemberian kompensasi dan kesejahteraan, keselamatan dan kesehatan kerja, dan hubungan industrial.

Manajemen sumber daya manusia sebagai suatu perencanaan pengorganisasian, pelaksanaan, dan pengawasan terhadap pengadaan, pengembangan, pemberian balas jasa, pengintegrasian, pemeliharaan, dan pemisahan tenaga kerja dalam rangka mencapai tujuan organisasi (Mangkunegara, 2008)

Ada empat hal yg kian penting diperhatikan berkenaan dengan manajemen sumber daya manusia (MSDM) yaitu (Sule dan Saefullah, 2009):

a. Penekanan yg lebih dari biasanya terhadap pengintegrasian berbagai kebijakan sumber daya manusia dengan perencanaan bisnis.

b. Tanggung jawab pengelolaan sumber daya manusia tidak lagi terletak hanya pada manajer khusus, tetapi sekarang dianggap terletak pada manajemen lini senior.

c. Perubahan fokus dari hubungan serikat pekerja manajemen menjadi hubungan manajemen karyawan, dari kolektivisme menjadi individualisme.

d. Terbisa penekanan aksentuasi pada komitmen dan melatih inisiatif di mana manajer berperan sebagai penggerak dan fasilitator

\subsection{Rekruitmen}

Menurut Randall S. Schuler dan Susan E. Jackson dalam Nanang Nuryanta (2008) Rekrutmen antara lain meliputi upaya pencarian sejumlah calon karyawan yang memenuhi syarat dalam jumlah tertentu sehingga dari mereka perusahaan dapat menyeleksi orang-orang yang paling tepat untuk mengisi lowongan pekerjaan yang ada. 
Rivai (2009) menjelaskan rekrutmen sebagai suatu rangkaian kegiatan yang dimulai ketika sebuah perusahaan memerlukan tenaga kerja dan membuka lowongan sampai mendapatkan calon yang diinginkan atau memenuhi kualifikasi sesuai dengan jabatan atau lowongan yang ada.

Raymond A. Noe Dkk, (2011), Rekrutmen SDM didefiniskan sebagai praktik atau aktivitas apapun yang dijalankan oleh organisasi untuk mengidentifikasikan dan menarik para karyawan potensial

Perekrutan yang efektiif sangat penting, hal ini karena terdapat beberapa alasan yang mendasaro, yaitu ; Pertama, terjadi perubahan yang dramatis dimana pada beberapa negara muncul fenomena terjadi kekurangan tenaga kerja yang sesuai dengan kebutuhan perusahaan. Kedua, beberapa metode perekrutan lebih baik dari yang lain, tergantung dari jenis pekerjaan. Ketiga, keberhasilan rekrutmen akan tergantung pada luasan area masalah dan kebijakan rekrutmen (Dessler, 2011).

Menurut (Rivai \& Sagala, 2009) prinsipprinsip yang semestinya dilakukan dalam sebuah proses rekrutmen adalah sebagai berikut :

a. Mutu karyawan yang direkrut harus sesuai dengan kebutuhan yang diperlukan oleh perusahaan agar sesuai dengan kualifikasi jabatan yang akan diisi, dengan menganalisis deskribsi dan speksifikasi pekerjaan. b. Jumlah karyawan yang diperlukan harus sesuai dengan pekerjaan yang tersedia. Untuk itu perlu dilakukan peramalan kebutuhan tenaga kerja dan analisis terhadap kebutuhan tenaga kerja.

c. Biaya yang diperlukan minimal.

d. Memiliki perencanaan dan keputusankeputusan strategi tentang perekrutan.

e. Fleksibilitas

f. Pertimbangan-pertimbangan hukum

a. Kerakteristik orgnaisasional

Rekrutmrn dapat dilakukan dengan mengidentifikasikan dari berbagai sumber, mencakup internal (dalam perusahaan) maupun eksternal (luar perusahaan). (Rivai dan Sagala, 2009) ;

a. Sumber internal perusahaan yaitu ;

- Penawaran terbuka untuk suatu jabatan (job posting programs)
- Perbantuan pekerjaan (departing employees).

b. Sumber eksternal perusahaan, yaitu ;

- Walks-in dan writes-in yaitu pelamar yang datang langsung keperusahaan dan mengisi formulir lamaran kerja yang telah disediakan

- Rekomendasi dari karyawan (teman, anggota keluarga karyawan, atau karyawan dari perusahaan lain).

- Pengiklanan, menerbitkan iklan lowongan kerja di media-media cetakk atau elektronik.

- Agen penempatan tenaga kerja, menyediakan layanan informasi pekerjaan melalui papan pengumuman, 
publikasi secara periodic, website, email, dan media lainnya.

- Lembaga-lembaga pendidikan dan pelatihan yang mneggunakan tenaga kerja khusus yang menghasilkan calon calon SDM yang berkulitas.

- Departemen atau dinas tenaga kerja yang biasanya menampung dan memberikan izin kerja kepada banyak calon pelamar kerja.

- Organisasi profesi dan asosiasi-asosiasi, tempat dimana banyak tenaga ahli dan professional berkumpul dan saling bertukar informasi

- Head hunter yaitu pencari tenaga professional yang biasa diperuntukan untuk mencari profesinal di level manajemen menengah dan eksekutif.

\subsection{Penempatan Pegawai}

Penempatan adalah menempatkan calon karyawan yang diterima (lulus seleksi) pada jabatan atau pekerjaan yang membutuhkan dan sekaligus mendelegasikan authority kepada orang tersebut. (Hasibuan, 2010)

Penempatan ialah mengalokasikan para karyawan pada posisi kerja tertentu hal ini khusus terjadi pada karyawan baru. (Rivai, 2009)

Menurut Edy Sutrisno (2011), faktorfaktor yang perlu dipertimbangkan dalam penempatan pegawai adalah:
a) Faktor latar belakang pendidikan
b) Faktor kesehatan jasmani dan rohani
c) Faktor pengalaman kerja

d) Faktor umur sumber daya manusia

e) Faktor jenis kelamin

f) Faktor status perkawinan

g) Faktor minat dan hobi

Salah satu tujuan organisasi dalam menempatkan pegawainya secara tepat adalah agar pegawai tersebut dapat berdaya guna dan berhasil guna dalam melaksanakan pekerjaan yang menjadi tanggung jawabnya. Wibowo (2010) mengung-kapkan bahwa "maksud dan tujuan dari penempatan pegawai adalah untuk menempatkan pegawai sebagai unsur pelaksana pekerjaan pada posisi yang sesuai dengan kemampuan, kecakapan, dan keahliannya." Tujuan ini harus didukung oleh prinsip-prinsip yang dapat digunakan sebagai pedoman.

\subsection{Kinerja Pegawai}

Surya Dharma (2010) yang mengartikan kinerja sebagai, hasil kerja yang dapat dicapai oleh seseorang atau kelompok orang dalam suatu organisasi, sesuai dengan wewenang adan tanggung jawab masingmasing dalam rangka upaya mendapai tujuan organisasi bersangkutan secara ilegal, tidak melanggar hukum dan sesuai dengan moral maupun etika.

Sementara Wibowo

(2010) mengemukakan bahwa kinerja adalah hasil atau tingkat keberhasilan seseorang secara keseluruhan selama periode tertentu di dalam melaksanakan tugas dibandingkan dengan berbagai kemungkinan, seperti standar hasil kerja, target atau sasaran atau kriteria yang 
telah ditentukan terlebih dahulu dan telah disepakati bersama.

Menurut Mangkunegara dalam Pasolong (2010) kinerja merupakan hasil kerja secara kualitas dan kuantitas yang dicapai oleh seseorang dalam melaksanakan fungsinya sesuai dengan tanggungjawab yang diberikan kepadanya.

Menurut Mathis, John H.Jackson (2011), syarat kriteria yang baik adalah reliable, realistis, representatif, acceptable, dan dapat digunakan prediksi (predictable).

a. Reliable, berarti apa yang diukur dan metode pengukuran yang memberikan hasil yang dapat diandalkan akurasinya (konsisten)

b. Realistis, berarti pengukuran kinerja memiliki standart tertentu

c. Representatif, berarti aspek-aspek kinerja yang diukur benar-benar mencerminkan jenis pekerjaan yang dinilai

d. Acceptable, berarti aspek-aspek, metode dan standart penilaian dapat diterima pegawai dan organisasi

e. Predictable, berarti hasil penilaian dapat digunakan utnuk memprediksi kinerja dimasa yang akan datang. Jika kriteria suatu pekerjaan sudah ditentukan, maka langkah berikutnya dalam mengukur kinerja (job performance) adalah mengumpulkan informasi yang berhubungan dengan hal tersebut dari seorang pegawai.

\section{METODOLOGI PENELITIAN}

\subsection{Tempat Penelitian}

Penelitian ini dilakukan pada Kinerja pada Satuan Kerja Dinas Bina Marga Dan Tata Ruang Provinsi Banten. Adapun obyek penelitiannya adalah karyawan atau pegawai tetap.

\subsection{Populasi dan Sample}

Populasi adalah sekumpulan data yang memiliki karakteristik yang sama dan menjadi objek pengamatan dalam penelitian. Populasi penelitian ini adalah seluruh pada pegawai Satuan Kerja Dinas Bina Marga Dan Tata Ruang Provinsi Banten sebanyak 36 orang .

Sampel merupakan bagian dari populasi yang memilki karakteristik yang dapat mewakili populasi. Dalam penelitian ini yang digunakan adalah seluruh populasi yang ada, sebanyak 36 orang pegawai pada Marga Dan Tata Ruang Provinsi Banten.

\subsection{Sumber dan Jenis Data}

Sumber data dalam penelitian ini adalah data primer, yaitu data yang diperoleh secara langsung dari nara sumber atau responden.

Jenis data dalam penelitian ini adalah data kualitatif, yang berupa jawaban dari reaponden melalui kuesioner yang telah disiapkan.

Data yang telah dikumpulkan, selanjutnya dikelompokkan, dan dilakukan tabulasi, selanjunya dilakukan perhitungan. Pembobotan dilakukan dengan menggunakan 
Skala Linkert pada jawaban responden untuk masing-masing variabel yang diteliti dengan pembobotan 1 (satu) untuk jawaban terendah dan 5 (lima) untuk jawaban tertinggi, dengan perincian sebagai berikut :

$$
\begin{aligned}
& 5 \text { : Sangat setuju } \\
& 4 \text { : Setuju } \\
& 3 \text { : Ragu-ragu } \\
& 2 \text { : Tidak setuju } \\
& 1 \text { : Sangat tidak setuju }
\end{aligned}
$$

\subsection{Metode Pengumpulan Data}

Pengumpulan data dalam penelitian ini melalui kuesioner, dimana dalam daftar pertanyaan tersebut, responden telah diberikan alternatif jawaban, sehingga responden akan memilih salah satu jawaban Metode ini mengukur setiap penilaian responden melalui pemberian bobot pada setiap jawaban pertanyaan.

\subsection{Metode Analisis Data}

Penelitian ini merupakan penelitian kausalitas, dimana mengukur pengaruh antara variabel bebas dengan variabel terikat. Metode analisis data dalam penelitian ini menggunakan analisis statistik dengan model persamaan regresi untuk mengukur bentuk hubungan antara variabel bebas dengan variabel terikat. Adapun persamaannya adalah sebagai berikut :

$$
\mathrm{Y}=\mathrm{a}+\mathrm{b}_{1} \mathrm{X}_{1}+\mathrm{b}_{2} \mathrm{X}_{2}+\mathrm{e} \text {. }
$$

Notasi :

$$
\begin{aligned}
\mathrm{Y} & =\text { Kinerja Pegawai } \\
\mathrm{X}_{1} & =\text { Rekrutmen Pegawai } \\
\mathrm{X}_{2} & =\text { Penempatan pegawai } \\
\mathrm{a} & =\text { Konstanta } \\
\mathrm{b}_{1} & =\text { Koefisien regresi Rekrutmen Pegawai } \\
\mathrm{b} 2 & =\quad \text { Koefisien regresi Penempatan } \\
& \text { Pegawai } \\
\mathrm{e} & =\text { Kesalahan estimasi }
\end{aligned}
$$

Sedangkan untuk mengukur pengaruh variabel bebas terhadap variabel terikat secara parsial menggunakan hipotesis dengan membandingkan antara $t_{\text {hitung }}$ dengan $t_{\text {tabel. }}$. Untuk mengukur pengaruh secara simultan, maka membandingkan antara $F_{\text {hitung }}$ dengan $\mathrm{F}_{\text {tabel. }}$. Dalam pengolahan data menggunakan software SPSS versi 20.

\section{ANALISIS DAN PEMBAHASAN}

\subsection{DESKRIPSI DATA}

Data dalam penelitian ini merupakan pagawai di lingkungan Satuan Kerja Dinas Bina Marga Dan Tata Ruang Provinsi Banten sebanyak 36 orang, yang terdiri dari 28 orang laki-laki dan 8 perempuan. Pegawai tersebut memiliki masa kerja dari 1 tahun sampai dengan 19 tahun. Sedangkan usia antara 20 tahun sampai dengan 50 tahun.

\subsection{ANALISIS DATA}

\subsubsection{Uji Validitas dan Reliabilitas}

Uji validitas ini merupakan pengujian validitas tiap butir atau disebut juga analisis item, yaitu mengkorelasikan nilai tiap butir dengan nilai total yang merupakan jumlah tiap nilai butir. . Dengan nilai $r$ tabel pada tingkat signifikan 0,05 dua arah (two-tails), 
atau pada tingkat signifikan $0,05: 2=0,025$ dengan $\mathrm{n}$ sebanyak 36 , sehingga $\mathrm{df}=\mathrm{N}-2$ ( $36-2=34$ ), maka nilai df atau $r_{\text {tabel }}$ menunjukkan nilai 0,329 .

Uji reliabilitas adalah data untuk mengukur suatu kuesioner yang merupakan indikator dari variabel atau konstruk. Suatu kuesioner dikatakan reliabel atau handal jika jawaban seseorang terhadap pernyataan adalah konsisten atau stabil dari waktu ke waktu. Kehandalan yang menyangkut kekonsistenan jawaban jika diujikan berulang pada sampel yang berbeda, untuk mengukur reliabilitas dengan uji statistik Cronbach Alpha (á)

Berdasarkan hasil output SPSS nilai korelasi untuk seluruh item nilainya lebih dari 0,329 maka dapat disimpulkan bahwa item-item tersebut berkorelasi signifikan dengan skor total (dinyatakan valid) atau dapat dikatakan bahwa butir instrument tersebut valid. Sedangkan dalam uji reliabilitas Karena nilai alpha lebih besar dari 0,329, maka dapat disimpulkan bahwa butirbutir instrumen penelitian adalah reliabel.

\subsubsection{Uji Normalitas dan Linieritas}

Dari hasil output SPSS uji normalitas diperoleh nilai siginifikansi (Asymp. Sig (2tiled) sebesar 0,100. Dimana nilai tersebut lebih besar dari 0,05, sehingga dapat di simpulkan bahwa data yang diuji berdistribusi normal.

Sedangkan hasil uji linieritas diperoleh nilai signifikansi 0,998 , nilai tersebut lebih besar dari 0,05 yang artinya terdapat hubungan linier secara signifikan antara variabel rekrutmen pegawai dan penempatan pegawai dengan kinerja pegawai.

\subsubsection{Regresi Berganda}

Pengolahan data dengan menggunakan SPSS, diperoleh output persamaan regresi seperti tersaji dalam tabel dibawah ini :

Tabel 4.1 Regresi Linier Berganda

Berdasarkan tabel tersebut diatas diperoleh persamaan regresi berganda sebagai berikut :

\section{$Y=27,909-0,333 X_{1}+0,495 X_{2}$}

Dari persamaan regresi tersebut menunjukkan bahwa, jika variabel $\mathrm{X}_{1}$ dan $\mathrm{X}_{2}$ nilainya 0 (nol), maka Kinerja Pegawai nilanya sebesar 27,909. Sedangkan variable Rekrutmen Pegawai $\left(\mathrm{X}_{1}\right)$ berpengaruh negatif sebesar 0,333 terhadap Kinerja Pegawai (Y). Hal ini berarti, jika rekrutmen pegawai naik, maka kinerja pegawai turun dan sebaliknya jika rekrutmen turun kinerja naik . Variabel Penempatan Pegawai $\left(X_{2}\right)$ perpengaruh positif sebesar 0,495 terhadap Kinerja Pegawai (Y).

Hal ini berarti jika penempatan pegawai naik, maka kinerja juga naik, dan sebaliknya jika penempatan pegawai turun, maka kinerja juga turun.

\subsubsection{Uji Asumsi Klasik}

\section{a. Uji Multikolinearitas}

Berdasarkan pada tabel 4.1 dapat dijelaskan sebagai berikut : 
1) Nilai VIF untuk variabel Rekrutmen Pegawai $1.164<5$, maka dapat dinyatakan, bahwa variabel ini tidak terjadi gejala multikolinearitas.

2) Nilai VIF untuk variabel Penempatan pegawai $1.164<5$, maka variabel Penempatan Pegawai dapat dinyatakan tidak terjadi gejala multikolinearitas.

\section{b. Uji Autokorelasi}

Uji autokorelasi untuk menguji ada tidaknya korelasi yang terjadi antara residual pada satu pengamatan dengan pengamatan lain pada model regresi. Prasyarat yang harus terpenuhi adalah tidak adanya autokorelasi pada model regresi. Uji autokorelasi dilakukan berdasarkan kelas interval nilai Durbin Watson (DW).

Berdasarkan hasil pengolahan data diperoleh output SPSS untuk Model Summary sebagai berikut :

Tabel 4.2.

Hasil Uji Autokorelasi

Model Summary ${ }^{\mathrm{b}}$

\begin{tabular}{|c|l|r|r|r|r|}
\hline Model & $R$ & R Square & $\begin{array}{c}\text { Adjusted R } \\
\text { Square }\end{array}$ & $\begin{array}{c}\text { Std. Error of } \\
\text { the Estimate }\end{array}$ & $\begin{array}{c}\text { Durbin- } \\
\text { Watson }\end{array}$ \\
\hline 1 &, $408^{\mathrm{a}}$ &, 167 &, 116 & 6,735 & 2,179 \\
\hline
\end{tabular}

a. Predictors: (Constant), PENEMPATAN PEGAWAI, REKRUITMAN PEGAWAI

b. Dependent Variable: KINERJA PEGAWAI

Pada tabel diatas, besarnya nilai hitung Durbin-Watson sebesar 2,179. Berdasarkan kriteria yang ada, maka nilai tersebut berada pada interval 1,60 - 2,41, dimana interval tersebut menunjukkan tidak ada autokorelasi. Sehingga dapat disimpulkan bahwa model regresi dalam penelitian ini tidak terjadi autokorelasi.

\section{c. Uji Heterokedastisitas}

Pengujian menggunakan tingkat signifikansi 0,05 dengan uji 2 sisi. Jika korelasi antara variabel independen dengan residual di dapat signifikansi lebih dari 0,05

\begin{tabular}{|c|c|c|c|c|c|c|c|}
\hline \multicolumn{8}{|c|}{ Coefficients ${ }^{\mathrm{a}}$} \\
\hline \multirow[t]{2}{*}{ Model } & \multicolumn{2}{|c|}{$\begin{array}{l}\text { Unstandardized } \\
\text { Coefficients }\end{array}$} & \multirow{2}{*}{\begin{tabular}{|c|}
$\begin{array}{r}\text { Standardized } \\
\text { Coefficients }\end{array}$ \\
Beta \\
\end{tabular}} & \multirow[t]{2}{*}{$\mathrm{t}$} & \multirow[t]{2}{*}{ Sig. } & \multicolumn{2}{|c|}{ Collinearity Statistics } \\
\hline & $\bar{B}$ & $\begin{array}{c}\text { Std. } \\
\text { Error }\end{array}$ & & & & Tolerance & VIF \\
\hline (Constant) & 27,909 & 13,983 & & 1,996 &, 054 & & \\
\hline $\begin{array}{l}\text { REKRUITMAN } \\
1 \text { PEGAWAI }\end{array}$ &,- 333 & ,427, &,- 133 &,- 778 &, 442 & ,859 & 1,164 \\
\hline $\begin{array}{l}\text { PENEMPATAN } \\
\text { PEGAWAI }\end{array}$ &, 495 & , 193 & 439, & 2,563 &, 015 &, 859 & 1,164 \\
\hline
\end{tabular}

maka dapat dikatakan bahwa tidak terjadi masalah heteroskedastisitas pada model regresi. Berdasarkan hasil pengolahan data diperoleh output SPSS untuk Model Summary sebagai berikut :

Tabel 4.3.

Uji Heterokedastisitas

\begin{tabular}{|c|c|c|c|c|c|}
\hline \multicolumn{6}{|c|}{ Correlations } \\
\hline & & & $\begin{array}{c}\text { REKRUTMEN } \\
\text { PEGAWAI }\end{array}$ & $\begin{array}{l}\text { PENEMPATAN } \\
\text { PEGAWAI }\end{array}$ & ABS_RES \\
\hline \multirow{9}{*}{$\begin{array}{c}\text { Spearman's } \\
\text { rho }\end{array}$} & \multirow{3}{*}{$\begin{array}{l}\text { REKRUTMEN } \\
\text { PEGAWAI }\end{array}$} & $\begin{array}{l}\text { Correlation } \\
\text { Coefficient }\end{array}$ & 1,000 & & 176 \\
\hline & & Sig. (2-tailed) & . & ,002 & ,304 \\
\hline & & $\mathbf{N}$ & 36 & 36 & 36 \\
\hline & \multirow{3}{*}{$\begin{array}{l}\text { PENEMPATAN } \\
\text { PEGAWAI }\end{array}$} & Correlation & ,505* & 1,000 & 287 \\
\hline & & Sig. (2-tailed) & ,002 & . & ,089 \\
\hline & & $\mathrm{N}$ & 36 & 36 & 36 \\
\hline & \multirow{3}{*}{ ABS_RES } & $\begin{array}{l}\text { Correlation } \\
\text { Coefficient }\end{array}$ & 176 & 287 & 1,000 \\
\hline & & Sig. (2-tailed) & ,304 & ,089 & . \\
\hline & & $\mathbf{N}$ & 36 & 36 & 36 \\
\hline
\end{tabular}

Berdasarkan tabel 4.3 di atas, menunjukan nilai korelasi kedua variabel independen dengan Unstandardized Residual memiliki nilai signifikansi lebih dari 0,05, yaitu untuk variabel Rekrutmen pegawa 0,304 dan sebesar 0,089 untuk variabel 
penempatan pegawai Karena signifikansi lebih dari 0,05 maka dapat disimpulkan bahwa tidak terjadi masalah heteroskedastisitas pada model regresi dalam penelitian ini.

\subsubsection{Uji Hipotesisi}

\section{a. Uji Hipotesisi Parsial}

Uji hipotesis parsial dalam penelitian ini mengukur pengaruh secara parsial (individu) dari variabel-variabel independen (Rekrutmen Pegawai dan Penempatan Pegawai) terhadap variabel dependen (Kinerja Pegawai). Pengambilan keputusan dilakukan dengan membandingkan antara nilai $t_{\text {hitung }}$ masing-masing koefisien regresi dengan nilai $t_{\text {tabel }}$ sesuai dengan taraf signifikansi yang digunakan 0,05. Sementara itu hasil perhitungan nilai $t_{\text {hitung dari kedua }}$ variabel independen tersebut terhadap Kinerja Pegawai disajikan pada tabel dibawah ini :

Tabel 4.4.

Hasil Uji Hipotesisi Parsial Coefficients $^{\mathrm{a}}$

\begin{tabular}{|c|c|c|c|c|c|}
\hline \multirow[t]{2}{*}{ Model } & \multicolumn{2}{|c|}{$\begin{array}{c}\text { Unstandardized } \\
\text { Coefficients }\end{array}$} & $\begin{array}{r}\text { Standardized } \\
\text { Coefficients } \\
\end{array}$ & \multirow[t]{2}{*}{$\mathrm{t}$} & \multirow[t]{2}{*}{ Sig. } \\
\hline & B & $\begin{array}{l}\text { Std. } \\
\text { Error }\end{array}$ & Beta & & \\
\hline (Constant) & 27,909 & 13,983 & & 1,996 & ,054 \\
\hline $\begin{array}{l}1 \text { REKRUITMAN } \\
\text { PEGAWAI }\end{array}$ &,- 333 &, 427 &,- 133 &,- 778 &, 442 \\
\hline $\begin{array}{l}\text { PENEMPATAN } \\
\text { PEGAWAI }\end{array}$ & 495, & , 193 & 439, & 2,563 & ,015, \\
\hline
\end{tabular}

Berdasarkan tabel di atas besarnya nilai

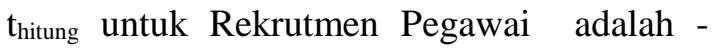
0,778, dan thitung untuk Penempatan Pegawai sebesar 2, 563 sedangkan $\mathrm{t}_{\text {tabel }}$ pada taraf signifikan 5\% sebesar 2,020.
Hasil uji hipotesis berdasarkan tabel diatas dapat di simpulkan bahwa :

1) Nilai thitung untuk variabel Rekrutmen Pegawai lebih kecil dari $\mathrm{t}$ tabel $\left(\mathrm{t}_{\text {hitung }}<\right.$ $\left.t_{\text {tabel}}\right)$. Hal ini berarti, bahwa variabel Rekrutmen Pegawai tidak berpengaruh terhadap Kinerja Pegawai . Sehingga $\mathrm{H}_{0}$ diterima dan Ha ditolak, artinya secara parsial variabel bebas tidak berpengaruh terhadap variabel terikat.

2) Nilai thitung untuk variabel Penempatan Pegawai lebih besar dari $\mathrm{t}$ table ( $\mathrm{t}_{\text {hitung }}>$ $\left.t_{\text {tabel }}\right)$. Hal ini berarti, bahwa variabel Penempatan Pegawai berpengaruh terhadap Kinerja Pegawai . Sehingga $\mathrm{H}_{0}$ ditolak dan Ha diterima, artinya secara parsial variabel bebas berpengaruh terhadap variabel terikat.

\section{b. Uji Hipotesisi Simultan}

Dalam penelitian ini uji hipotesis simultan menggunakan Uji F. Uji F ini bertujuan untuk mengetahui pengaruh secara simultan variabel independen, yaitu Rekrutmen Pegawai dan Penempatan Pegawai terhadap variabel dependen, yaitu Kinerja Pegawai . Hasil uji F dari pengolahan data dengan SPSS dapat dilihat pada tabel berikut ini :

Tabel 4.5.

Hasil Uji Hipotesisi Simultan

ANOVA $^{\mathrm{a}}$

\begin{tabular}{|l|r|r|r|r|r|}
\hline \multicolumn{1}{|l|}{ Model } & $\begin{array}{r}\text { Sum of } \\
\text { Squares }\end{array}$ & Df & Mean Square & F & Sig. \\
\hline \multirow{4}{*}{$1 \quad$ Residual } & 299,813 & 2 & 149,906 & 3,304 &, $049^{\mathrm{b}}$ \\
& 1497,076 & 33 & 45,366 & & \\
& 1796,889 & 35 & & & \\
\hline
\end{tabular}

b. Predictors: (Constant), PENEMPATAN PEGAWAI, REKRUITMAN PEGAWAI 
Dari table atas dapat menunjukkan nilai $F_{\text {hitung }}$ sebesar 3,304 sedangkan $F_{\text {tabel }}$ pada taraf signifikan $5 \%$ sebesar 2,88 sehingga dari hasil penghitungan menunjukkan bahwa $\mathrm{F}_{\text {hitung }}$ lebih besar dari $\mathrm{F}_{\text {tabel }}(3,304>2,88)$, Dengan demikian Ho ditolak dan $\mathrm{Ha}$ diterima. Sehingga dapat simpulkan bahwa secara bersama-sama Rekrutmen Pegawai dan Penempatan Pegawai berpengaruh terhadap Kinerja Pegawai, sesuai dengan hipotesis alternatif yaitu Ha diterima.

\subsubsection{Koefisien Determinasi}

Koefisien ini menunjukkan seberapa besar persentase variasi variabel independen yang digunakan dalam model mampu menjelaskan variasi variabel dependen, yang ditunjukkan dengan hasil dari nilai R square .

Hasil pengolahan data, koefisien determinasi dapat disajikan sebagai berikut:

Tabel 4.6. Koefisien Determinasi

\begin{tabular}{|c|c|c|c|c|}
\hline \multicolumn{5}{|c|}{ Model Summary } \\
\hline Model & $\bar{R}$ & R Square & $\begin{array}{c}\text { Adjusted R } \\
\text { Square }\end{array}$ & Std. Error of the Estimate \\
\hline 1 &, $408^{\mathrm{a}}$ &, 167 & 116 & 6,735 \\
\hline
\end{tabular}

Berdasarkan hasil yang tersaji pada tabel diatas, nilai koefisien determinasi $\left(\mathrm{R}^{2}\right)$ yaitu sebesar 0.167 atau $16,7 \%$. Hal ini berarti bahwa sebesar $16,7 \%$ variasi Kinerja pegawai yang bisa dijelaskan oleh variasi variabel independen yaitu Rekruitmen pegawai dan Penenempatan pegawai. Sedangkan sisanya sebesar $100 \%-16,7 \%=$ $83,3 \%$ dipengaruhi oleh variabel lain yang tidak dimasukkan dalam penelitian ini. Nilai tersebut sangat kecil, yang artinya adalah rekrutmen dan penempatan pegawai di lingkungan Satuan Kerja Dinas Bina Marga Dan Tata Ruang Provinsi Banten tidak memiliki dampak yang signifikan terhadap kinerja pegawai.

\subsection{PEMBAHASAN}

Pegawai merupakan bagian terpenting dalam kegiatan organisasi maupun usaha dalam mencapai sasaran dan tujuannya. Setiap organisasi maupun perusahaan tujuan yang telah ditetapkan, dengan harapan tujuan tersebut dapat tercapai. Salah satu faktor yang mempengaruhi tercapainya tujuan perusahaan adalah kinerja pegawai. Dengan asumsi bahwa jika kinerja pegawai tinggi, maka akan tercipta kinerja team yang tinggi dan pada akhirnya kinerja perusahaan juga meningkat atau naik. Untuk mendapatkan kinerja pegawai yang tinggi, tentu saja banyak hal yang harus dilakukan oleh perusahaan mulai dari proses seleksi pegawai atau rekrutmen sampai dengan penempatan , pengembangan pegawai maupun aktivitas yang lain dalam rangka meningkatkan dan memotivasi kinerja pegawai.

Penelitian ini mengukur pengaruh antara rekrutmen dan penempatan terhadap kinerja pegawai di Satuan Kerja Dinas Bina Marga Dan Tata Ruang Provinsi Banten. 
Berdasarkan hasil analisis dan pengolahan data menunjukkan bahwa rekutmen dalam hal ini adalah proses seleksi sampai dengan penerimaan pegawai tidak memiliki pengaruh terhadap kinerja pegawai. Hal ini dapat dijelaskan bahwa dalam proses rekurutmen pada instansi ini melalui seleksi yang dilakukan dengan standar CPNS, sehingga calon pegawai tidak melalui seleksi secara khusus pada instansi tersebut. Oleh karena itu pegawai yang diterima merupakan hasil seleksi secara nasional. Oleh karena itu latar belakang pendidikan dan kompetensi tidak menjadi bagian yang berdampak pada kinerja pegawai. Pada instansi ini menerapkan pelatihan dan pendidikan sesuai dengan bidangnya dalam meningkatkan kemampuan dan ketrampilan pegawainya. Sehingga faktor inilah yang lebih dominan mempengaruhi kinerja pegawainya.

Penempatan pegawai dari hasil pengolahan dan analisis data menunjukan memiliki pengaruh terhadap kinerja pegawai. Hal ini dapat dijelakan bahwa pada instansi ini untuk bidang-bidang tertentu membutuhkan pegawai yang memiliki kemampuan khusus, sehingga untuk menempati jabatan tertentu diperlukan pegawai yang memiliki latar belakang ketrampilan, pendidikan dan keahlian sesuai dengan bidangnya. Dalam penelitian ini juga dapat dilihat dari hasil jawaban responden, bahwa pegawai yang memiliki latar belakan keahlian dan pendidikan sesuai bidangnya memiliki kinerja yang lebih baik, yaitu dalam hal ketepatan waktu pelaporan, kemampuan menyelesaikan setiap pekerjaan, sedikit kesalahan yang dilakukan serta pencapaian prestasi kerja yang mengalami peningkatan.

Pengukuran varian secara bersama-sama antara variabel rekrutimen dan penempatan pegawai dengan kinerja sangat kecil. Hal ini menunjukan bahwa rekrutmen dan penempatan pegawai bukan merupakan faktor yang dominan dalam mempengaruhi kinerja pegawai. Karena selain kedua faktor tersebut masih terdapat banyak faktor yang mempengaruhi pgawai, antara lain lingkungan kerja, kompensasi, gaya kepemimpinan, loyalitas pegawai dan masih banyak yang lainnya. Sehingga untuk penelitian selanjutnya dapat melengkapi atau menambahkan dengan variabel-variabel lainnya guna menghasilkan penelitian yang lebih baik.

\section{KESIMPULAN DAN SARAN}

\subsection{KESIMPULAN}

Berdasarkan hasil analisis dan pembahasan dalam penelitian yang telah dilakukan, maka dapat ditarik beberapa kesimpulan. Adapun kesimpulan dalam penelitian ini adalah sebagai berikut :

a. Rekrutmen Pegawai memiliki hubungan negatif dan Penempatan Pegawai memiliki hubungan positif terhadap Kinerja pegawai.

b. Rekrutmen pegawai tidak berpengaruh terhadap kinerja pegawai, sehingga $\mathrm{H}_{0}$ di terima dan $\mathrm{H}_{\mathrm{a}}$ di tolak. 
c. Penempatan pegawai berpengaruh terhadap kinerja pegawai, sehingga $\mathrm{H}_{0}$ di tolak dan terima dan $\mathrm{H}_{\mathrm{a}}$ di terima.

d. Rekrutmen pegawai dan penempatan pegawai secara bersama-sama berpengaruh terhadap kinerja pegawai, sehingga $\mathrm{H}_{0}$ di tolak dan terima dan $\mathrm{H}_{\mathrm{a}}$ di terima.

e. Varians variabel Rekrutmen pegawai dan Penenempatan pegawai mampu menjelaskan varians variasi Kinerja pegawai sangat kecil hanya sebesar $16,7 \%$, sedangkan sisanya sebesar $83,3 \%$ dijelaskan variabel lain yang tidak dimasukkan dalam penelitian ini.

\subsection{SARAN}

Berdasarkan hasil penelitian, maka ada beberapa saran atau masukan yang dapat disampaikan dalam rangka meningkatkan kinerja pegawai di lingkungan Satuan Kerja Dinas Bina Marga Dan Tata Ruang Provinsi Banten, adalah sebagai berikut :

a. Menempatkan pegawai sesuai dengan latar belakang pendidikan dan kemampuan

b. Melakukan seleksi pegawai secara selektif agar medapatkan pegawai yang memiliki keahlian sesuai dengan yang dibutuhkan.

c. Menambah program pelatihan dan pengembangan sumber daya pegawai agar dapat meningkatkan kinerjanya.

\section{Daftar Pustaka}

Ardana, I Komang dkk, 2012. Manajemen Sumber Daya Manusia . Yogyakarta: Graha ilmu

Arikunto, Suharsimi, 2012. Prosedur Penelitian. Rineka Cipta, Jakarta

Dharma, Surya, 2010. Manajemen Kinerja . Edisi ketiga Pustaka Pelajar: Yogyakarta.

Dessler, Gary, 2011. Manajemen SDM. Edisi Kesepuluh. Jakarta: PT. Indeks.

Edy Sutrisno, 2011. Manajemen Sumber Daya Manusia, Jakarta: Kencana.

Ghozali, Imam, 2005. Aplikasi Analisis Multivariate dengan Program SPSS edisi 3, Semarang: BP UNDIP

Handoko, T. Hani, 2011.Manajemen Personalia dan Sumber Daya Manusia .Yogyakarta : Liberty

Hariandja, Marihot Tua Efendi. 2002. Manajemen SDM (Pengadaan, Pengembangan, Pengkompensasian, dan Peningkatan Produktivitas Pegawai). Jakarta: PT. Grasindo.

Malayu Hasibuan S P, 2012 Manajemen Sumber Daya Manusia, Cetakan Keenam belas. Jakarta PT Bumi Aksara.

Mangkunegara A P, 2011. Manajemen Suber Daya Manusia . Perusahaan Bandung PT Remaja Rosdakarya.

Robert L. Mathis, John H.Jackson, 2011. Human Resource Management, Jakarta: Salemba Empat, 2011

Sedarmayanti, 2010. Manajemen Sumber Daya Manusia Reformasi Birokrasi dan Manajemen Pegawai Negeri Sipil,PT. Refika Aditama, Bandung.

Simanjuntak, Payaman J, 2011. Manajemen dan Evaluasi Kinerja (Edisi 3). Jakarta : Lembaga Penerbit FEUI 
Singarimbun, Masri dan Sofian Effendi, 2008. Metode Penelitian Survai. Jakarta: Anggota LP3ES Indonesia, anggota IKAPI

Sugiyono, 2010. Statistika untuk Penelitian, Bandung: CV Alfabeta

.............. 2011. Metode Penelitian Kuantitaif, Kualitatif, dan $R \& D$. Bandung: Alfabeta

Sutrisno, Edy, 2011. Manajemen Sumber Daya Manusia . Edisi Pertama, Cetakan ketiga, Kencana Prenada Media Group, Jakarta.

Wibowo, 2010. Manajemen Kinerja, Edisi Ke tiga, Rajawai Pers, Jakarta 